\title{
Correspondence
}

To the Editors

\section{Respiratory sinus arrhythmia reactivity: Clinical entity to be recognized in the present mass Covid-19 vaccination}

Sri Lanka Journal of Child Health, 2022: 51(1): 167

DOI: http://dx.doi.org/10.4038/sljch.v51i1.100034

(Key words: Covid-19, Vaccine, Arrhythmia, Anxiety)

Dear Editors,

Vaccination is currently a standard prevention strategy against Covid-19. The vaccination in adolescents by mRNA vaccine has just been approved. As a new vaccine, vaccine hesitancy usually occurs when there is news on possible adverse effect of Covid-19 vaccination. Good public health information is a key factor for promoting mass vaccination coverage. In adolescents an extremely, self-limited cardiac adverse event might occur $^{1}$. The abnormal electrocardiogram (ECG) following Covid-19 vaccination might be detected $^{1,2}$. However, the information on the event is usually shared in social media and it can cause anxiety for adolescents and their parents.

Respiratory sinus arrhythmia reactivity is a condition with increased heart rate with inspiration and decreased rate during expiration ${ }^{2,3}$. Such an abnormal ECG pattern in a patient with this condition is sinus arrhythmia and there might be a non-significant ST segment elevation. When a physician is consulted by a paediatric/adolescent mRNA Covid-19 vaccine recipient with a complaint of dyspnoea or palpitation, this kind of abnormal ECG might be observed. It is necessary to embark on a careful clinical examination and history taking, to rule out anxious states of children. Taking care of the anxiety of parents is also needed. In a case without clear clinical data or suspicious symptoms such as cardiac chest pain, use of cardiac biomarkers such as troponin can help exclude an organic cardiac problem. Finally, it is emphasized that Covid-19 vaccine is safe for adolescents and most cardiac complaints or post vaccination abnormal ECGs are usually the result of anxiety. A good pre-vaccination consultation and reassurance for any postvaccination complaint for both children and parents are the need of the hour.

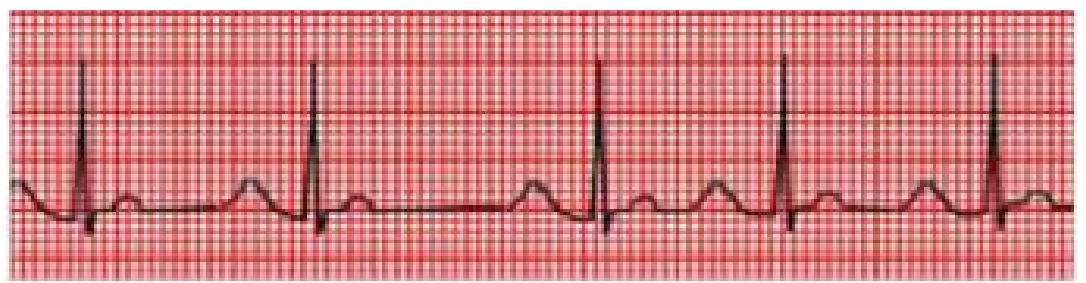

ECG example of post Covid-19 vaccination sinus arrhythmis in an soblescent with sinxiety

\section{References}

1. Bozkurt B, Kamat I, Hotez PJ. Myocarditis with Covid-19 mRNA vaccines. Circulation 2021; 144(6): 471-84. https://doi.org/10.1161/CIRCULATIONA HA. 121.056135

PMid: 34281357 PMCid: PMC8340726

2. Beauchaine TP, Bell Z, Knapton E, McDonough-Caplan H, Shader T, Zisner A. Respiratory sinus arrhythmia reactivity across empirically based structural dimensions of psychopathology: A metaanalysis. Psychophysiology 2019; 56(5): e13329.

https://doi.org/10.1111/psyp.13329

PMid: 30672603 PMCid: PMC6453712
3. Campbell AA, Wisco BE. Respiratory sinus arrhythmia reactivity in anxiety and posttraumatic stress disorder: A review of literature, Clinical Psychology Review 2021; 87: 102034

https://doi.org/10.1016/j.cpr.2021.102034 PMid: 33930767

\footnotetext{
*Pathum Sookaromdee ${ }^{1}$, Viroj Wiwanitkit ${ }^{2}$

${ }^{1}$ TWS Medical Centre, Bangkok Thailand

${ }^{2}$ Honorary Professor, Dr. DY Patil University, Pune, India

*Correspondence: pathumsook@gmail.com

iD

https//orcid.org/ 0000-0002-8859-5322

Open Access Article published under the Creative Commons Attribution CC-BY@c) (i) License
} 